\title{
Integration or transformation? Looking in the future of Information and Communication Technology in education in Vietnam
}

\author{
Jef Peeraer $^{\mathrm{a}, *}$, Peter Van Petegem ${ }^{\mathrm{b}}$ \\ ${ }^{a}$ Flemish Association for Development Cooperation and Technical Assistance, Thao Vien guesthouse A3 rm 307, 1B Bac Son-Ngoc Ha, Hanoi, Vietnam \\ ${ }^{\mathrm{b}}$ University of Antwerp, Institute for Education and Information Sciences, Venusstraat 35, 2000 Antwerp, Belgium
}

A R T I C L E I N F O

\section{Article history:}

Received 6 May 2013

Received in revised form 29 April 2014

Accepted 19 September 2014

Available online 28 September 2014

\section{Keywords:}

Information and communication

technology in education

Country-specific developments

Delphi method

Policy development

\begin{abstract}
A B S T R A C T
Over the last two decades, crucial factors for Information and Communication Technology (ICT) in education have improved significantly in Vietnam. Nevertheless, it is clear that, as in other countries, no educational revolution is taking place. We argue that there is a need for a broad dialogue on the future of ICT in education in Vietnam as discussion of ideas about future possibilities can be instrumental in rationalizing and generating educational change. We explore how a group of key players representing the public and private sector as well as development partners in the field look at the future of ICT in education in the country. Following the Delphi method, these key players assessed in different survey rounds the current situation of ICT in education, identified a series of targets and were asked to assess these targets in respect of their importance. The key players reached a consensus that the purpose of technology integration is to achieve learning goals and enhance learning. However, there is more controversy on targets that could potentially transform education practice in Vietnam. We discuss the value of the Delphi technique and argue for increased participation of all involved stakeholders in policy development on ICT in education.
\end{abstract}

(c) 2014 Elsevier Ltd. All rights reserved.

\section{Introduction}

Related to ICT $^{1}$ in education in Vietnam, a turning point seems to be drawing near. For over a decade, an extended body of guidelines and policies has been put in place, addressing several aspects of integration of ICT in education (Peeraer \& Van Petegem, 2011b). Starting from 2000, ICT has been placed on the education reform agenda both as an object of education and as an important pedagogical tool for innovating teaching methodology. Furthermore, impressive progress on improving access to ICT has been made in Vietnam, as is shown in the ICT Development Index (International Telecommunication Union, 2009, 2011). In a recent report of SEAMEO (2010), ${ }^{2}$ it is stated that the policy guidelines and ICT infrastructure and resources in schools in Vietnam may have provided the necessary and sufficient conditions for some schools to transform their ICT-mediated teaching and learning practices. Nevertheless, it is clear that, as in other countries, no

\footnotetext{
* Corresponding author. Tel.: +84 0909824 889; fax: +84 47347290. E-mail addresses: jef.peeraer@gmail.com, jef_oi@yahoo.com (J. Peeraer), peter.vanpetegem@ua.ac.be (P. Van Petegem).

1 Information and Communication Technology.

2 Southeast Asian Ministers of Education Organization.
}

educational revolution is taking place yet. Vietnamese teacher educators for example, mostly use ICT in ways that mainly replace traditional teaching practice. However, regular, innovative use of ICT in support of student learning is still very improbable for most (Peeraer \& Van Petegem, 2011a).

Research has been carried out worldwide on factors influencing or constraining the use of ICT in education and these factors have been addressed in ways to create a breakthrough (e.g. Drent \& Meelissen, 2008; Groff \& Mouza, 2008; Mumtaz, 2000). At the same time, critical voices are raised with regards to the entire discourse on integration of ICT in education (e.g. Bigum \& Rowan, 2008; Kirkup \& Kirkwood, 2005; Selwyn, 2007). The questions for Vietnam are now what to aim for and how to move ahead. Earlier we argued that Vietnam and other emerging developing countries could make a difference and aim to go beyond an access and skills based approach, striving instead for integration of ICT in education as a tool for creative learning (Peeraer \& Van Petegem, 2011a).

We believe that a look into the future might put current achievements in perspective. As argued by Williams (2005), extrapolations from emergent trends can have a value in promoting understanding of the present situation as well as in identifying needs for the future. It is clear, as argued by Selwyn (2012), that technology is certainly not an uncontested or 
uncontroversial area of education and many of the issues that surround education and technology are the fundamentally political questions that are always asked of education and society - i.e. questions about what education is, and questions about what education should be.

Accordingly, we brought together a selected group of key players in the field of ICT in education in Vietnam and facilitated a reflection process on targets and priorities in respect of ICT in education in Vietnam for 2020. Facer and Sandford (2009) recommend such forums to enable educators, policy makers, learners, communities, business and parents to explore how best to appropriate or resist emerging socio-technical developments, and to debate the political and ethical questions raised by 'the unpredictability and serendipity of social and technical outcomes' (Williams in Facer \& Sandford, 2009). From discussions of national strategy, to day-to-day interactions between educators and learners, ideas about possible futures can be instrumental in rationalizing and generating educational change (Facer \& Sandford, 2009). Also in Vietnam, a stronger dialogue among practitioners, researchers and policy makers can be achieved. In our study, we facilitated this by following the Delphi method wherein different survey rounds key players assessed the current situation of ICT in education, identified a series of targets for the future and were asked to assess these targets on their importance.

In this research paper we start with a critical perspective on the future of ICT in education. After clarifying the research objectives, we describe in detail the Delphi method and how we applied the method for this study. For each round of the study we present the major findings, after which we draw conclusions and discuss about how to move ahead with ICT in education in Vietnam.

\section{The future of ICT and education}

ICT is one of the most visible symbols of globalization and educational innovation (Power, 2007) and is often presented as both a cause and a consequent driver for educational innovation and change (Clegg et al., 2003). Different rationales that are behind ICT in education policies have been identified (e.g. Hawkridge, 1990; Kozma, 2008; Selwyn, 1999; Tondeur, van Braak, \& Valcke, 2007), going from an economic rationale, a social rationale, and an educational rationale, to a catalytic rationale (Kozma, 2008). Within these discourses, ICT is often presented as 'inevitable' (James \& Hopkinson, 2009) and increasingly ubiquitous. It has already been observed that, currently, ICT has been used far beyond enhancing teaching and learning to include promoting research, scholarly community engagement, and administration (Balasubramanian et al., 2009). The integration of ICT is moving beyond getting personal computers into the hands of learners and towards mobile technology, virtual world, and cloud computing amongst others (Hong \& Songan, 2011). Facer and Sandford (2009) argue however that technological determinism saturates many of the future educational visions promoted by policy-makers, industry and even some researchers. More and more researchers urge caution when speaking of the affordances of new technologies and when assuming that a given medium or technology will automatically bring about particular learning outcomes since there is nothing inherent in technology that automatically guarantees learning (e.g. John \& Sutherland, 2005). Robertson (2003) even points out a series of studies that have failed to find a positive relationship between ICT use and student achievement. On a somewhat more positive note, Collins and Halverson (2009) argue that we all know that technology has transformed our larger society, but that, nevertheless, it remains uncertain how the education sector responds to technological innovations.

What seems to be a critical uncertainty is the response of the education system which varies from rapid transformations in policy and practice at one extreme to resistance and incremental change at the other (Facer \& Sandford, 2009). Two particular observations serve to temper expectations: first, there has been a disappointingly slow uptake of ICT in education even though high investments have taken place in improving access to technologies and in improving the skills of teachers and learners; secondly, there has not been an educational revolution in teaching and learning (Selwyn, 2007). Bigum and Rowan (2008) also observe that despite the enormous reshaping of the planet's social, economic and political circumstances, supported by the global deployment of ICT, the focus in teacher education has remained largely at site, reflecting a similar focus in schools. Researchers emphasize the notion of ICT adoption as a staged or sequential process (Farrell \& Wacholz, 2003; Tearle, 2003). In the first place, investments are often made in technology and skills training, and ICT is seen as an object of education. However, the 2007 Asia Policy Forum on ICT integration into Education (World Links, 2007) suggested that ICT integration should not start with providing the technology and infrastructure but with educating the teachers. In much of the research on integration of ICT in education, different stages or phases are identified (e.g. in Mills \& Tincher, 2003). It has also been suggested to analyze ICT based innovations on a continuum ranging from the assimilation level through the transition level and up to the transformation level (Mioduser, Nachmias, Tubin, \& Forkosh-Baruch, 2003). UNESCO identifies four categories or stages of development concerning ICT use in education: emerging, applying, infusing and transforming (UNESCO, 2005, 2010). Education institutions or systems at the emerging stage have just begun to introduce computers. The focus in the classroom is often on learning basic ICT skills and identifying ICT components. At the applying stage, additional ICT equipment has been acquired, usually in countries where there are national ICT policies in place and where various ICT strategies are being trialed. Educators use ICT for professional purposes, focusing on improving their subject teaching in order to enrich how they teach with a range of ICT applications. At the infusing stage (or also called "integrating" or "embedding" stage), almost all classrooms are equipped, as are school offices and the library, and schools have internet connections. While teachers now integrate ICT in all aspects of their professional lives to improve their own learning as well as the learning of their students, ICT is not completely fused with other regular learning activities (UNESCO, 2010). It is in the most advanced, transforming stage of ICT-mediated teaching and learning pedagogies, that students' thinking processes are supported by ICT (SEAMEO, 2010). When this stage is reached, the whole ethos of the institution is changed: teachers and other support staff regard ICT as a natural part of the everyday life of their institutions, which have become centers of learning for their communities (UNESCO, 2010).

In previous research, the Peeraer and Van Petegem (2012) have developed an instrument that can be used for fundamental measurement of perceived use of ICT for teaching and support of student learning of the reference population, allowing for identification of stages of innovation of ICT integration. Applied in the framework of a study on the use of ICT by Vietnamese teacher educators, the findings clarify that the majority of Vietnamese teacher educators have a high probability to use ICT to replace their existing teaching practice or to enhance student learning from time to time. Nevertheless, regular, innovative use of ICT in support of student learning was still very improbable for most (Peeraer \& Van Petegem, 2012).

\section{Research objectives}

The aim of this study was to facilitate dialogue and cooperation on a wide range of operational components of ICT in education and 
transformation of education. To initiate this dialogue, key players were identified and invited to share their opinion on the current status of ICT in education in Vietnam as well as to identify targets for 2020. To make sure all of the factors that relate to ICT in education were addressed, the holistic framework of ICT in education, identified by SEAMEO (2010) was introduced to the key players. In their report on the status of ICT in education in Southeast Asian countries, SEAMEO identified 10 ICT in education dimensions based on the country case studies where these dimensions are necessary and sufficient conditions that support the integration of ICT in education (see Table 2). In order to make sense of the differences and commonalities among the countries, regions and areas, SEAMEO formulated indicators for the four stages of ICT in education from UNESCO's model of ICT Development in Education (UNESCO, 2005, 2010) on each of the 10 ICT in education dimensions.

The research objectives that are intertwined with this study are twofold:

- to identify targets for 2020 on ICT in education of a group of key players in the broad field of ICT in education in Vietnam;

- to measure the consensus amongst these key players on the importance of these identified targets for 2020.

Through identification of the targets and assessment of consensus on importance, the study aims in addition to explore and analyze the underlying mindset of the group of key players related to the future of education in Vietnam and the role of ICT therein.

\section{Research methodology}

To facilitate the dialogue and to identify targets and achieve consensus on importance, we have applied the Delphi technique. The Delphi technique is an anonymous multi-round surveying technique for gathering and synthesizing experts' and stakeholders' judgments and opinions on matters relating to complex policy considerations. The technique is a method for structuring a group communication process so that the process is effective in allowing a group of individuals, as a whole, to deal with a complex problem (Linstone \& Turoff, 2002).

In what follows we describe this technique in more detail. We argue why the technique is appropriate and how it has been applied for this study on the future of ICT in education in Vietnam.

\subsection{The Delphi technique}

The research literature clearly indicates that the Delphi technique has become a widely used and accepted method for gathering survey data from respondents within their domain of expertise (Hsu \& Sandford, 2007). The Delphi research and investigation technique utilizes experts in any given field to generate information in greater abundance and specificity than what is currently known or available. The conventional and most widely used Delphi process strives for consensus so that target issues can be more fully investigated based on the feedback of the people who are most knowledgeable and involved. Multiple iterations or rounds of data collection are the most unique aspect of the process, which allows the quality and relevance of the information concerning the target issue to become more precise and well defined (Hsu \& Sandford, 2012).

For this study, the technique is used for analyzing needs for educational policy and development in the field of ICT in education to develop a full range of alternatives and explore underlying assumptions. Furthermore, the Delphi technique is used as a method for consensus-building by using a series of questionnaires delivered using multiple iterations to collect data from a panel of selected subjects.

\subsection{Delphi rounds and participants}

In a Delphi exercise, the purpose of the survey is to structure communication among survey participants (Linstone \& Turoff, 2002). Even though there has been considerable variance in administrating the Delphi process, prescribed methodology requires that two cycles of questionnaires and feedback reports be used (Van de Ven \& Delbecq in Pollard \& Pollard, 2004). Three iterations are usually sufficient to collect the needed information and to reach a consensus in most cases (Cyphert and Gant in Hsu \& Sandford, 2007). For this study, a three-round Delphi process involving three cycles of online questionnaires and feedback reports was organized, in the period of April to October 2012.

Before the first round, an initial key players' meeting was held in March 2012 in Hanoi, where the framework of 10 dimensions of ICT in education (SEAMEO, 2010) was introduced. Overall, Delphi monitors seek to create a panel that reflects a wide range of experience and a diversity of opinions on the subjects that are being considered (Masser \& Foley in Novakowski \& Wellar, 2008) The participation list of the meeting was carefully compiled and participants were selected to represent the broad network of actors in the field, with varied occupations in both the public and private sector, as well as development partners. After that meeting, the same key players were invited to participate in the first survey round. With an e-mail invitation they were directed to the online Delphi survey. As suggested by Novakowski and Wellar (2008), the literature review and in particular the SEAMEO study enabled us to give the initial survey shape and content. As done in other Delphi studies (cf. Hung, Altschuld, \& Lee, 2008), semi-structured questions were used for the first round: for each of the 10 dimensions, participants were asked to share their opinion on the current status of ICT in education in Vietnam, as well as to identify realistic aims to achieve by 2020 . Even though key players met at the start of the study and at later moments in the process, in all subsequent Delphi rounds it was made clear that data was collected and processed anonymously. The online survey was completed by 20 key players out of 34 invited and confirmed participants for the initial meeting. From the 20 key players who completed the initial Delphi survey, $25 \%$ indicated they are development partners while $55 \%$ are from the public sector. The remaining $20 \%$ of key players are from the private sector. Over these sectors, their occupations range from technology developer and service provider, to educational researcher, lecturer, trainer/ tutor and school head, university dean or head of department, to policy maker (see Table 1 ). This group of key players are involved in all dimensions of ICT in education identified by SEAMEO (2010).

The first Delphi round, which is in this study treated as a fullblown round, is as well an information-seeking round, as suggested by Novakowski and Wellar (2008). The respondent input led to an assessment of the current status of ICT in education in Vietnam and a list of targets for 2020 addressing 10 dimensions of ICT in education. After content analysis and further categorization by the researchers to identify the major themes (recommended by Powell, 2003), this led to a set of survey items for the subsequent Delphi rounds. The findings were shared with all key players in a feedback report.

For the second survey round, that was launched in May 2012; the same key players were invited, as well as other stakeholders that had been identified by the key players who participated in the initial meeting through snowballing. In total, 26 key players completed the second online survey. As shown in Table 1, these participants again represented the broad and varied network of 
Table 1

Overview of participants in Delphi rounds.

\begin{tabular}{llll}
\hline Occupation & Round 1 & Round 2 & Round 3 \\
\hline $\begin{array}{l}\text { Policy maker (at national, } \\
\quad \text { regional, local level) }\end{array}$ & 2 & 2 & 2 \\
$\begin{array}{l}\text { School head, University dean, } \\
\quad \text { Head of dept., or equivalent ... }\end{array}$ & 5 & 3 & 2 \\
Teacher trainer & 0 & 2 & 2 \\
Lecturer & 1 & 2 & 2 \\
University professor & 0 & 2 & 2 \\
Educational researcher & 4 & 3 & 3 \\
Trainer, tutor, learning & 2 & 3 & 2 \\
$\quad$ facilitator & 0 & & \\
Technology provider & 4 & 1 & 1 \\
Service provider & 1 & 4 & 3 \\
Technology developer & 1 & 1 & 1 \\
Other & Round 1 & Round 2 & Round 3 \\
Sector & 11 & 13 & 12 \\
\hline Public sector & 4 & 5 & 4 \\
Private sector & 5 & 8 & 6 \\
Development partner & $\mathbf{2 0}$ & $\mathbf{2 6}$ & $\mathbf{2 2}$ \\
Total & & & 2 \\
\hline
\end{tabular}

key players in the field. They were asked to assess each of the targets that were identified in the first survey round on their importance or possible impact in light of the current educational context in Vietnam. The targets were rated on a scale from 1 (Unimportant) to 10 (Very important). Once returned, descriptive statistics (mean and standard deviation) for the group ratings were calculated and shared with all participants in a report. The findings were also shared during a follow-up key players meeting in Hanoi after the summer recess, in September 2012. As suggested by Hsu and Sandford (2007), as a result of round two, areas of disagreement and agreement were identified (see next section on defining consensus and priority).

For the third and final round, that was launched in September 2012, after the follow-up key players meeting, all key players were invited to re-rate the targets on which no consensus was achieved in the second survey round. As suggested by Rayens and Hahn (2000), items for which consensus had been achieved in the second round were not included in this stage. This time, descriptive quantitative, as well as qualitative, information about how the group responded, as a whole, was provided. In total, 22 key players out of 26 who had participated in the second survey round completed the third online survey (for composition, see again Table 1). The key players were asked to review each item, consider the group response and then re-rate the items, taking that information into account, or, alternatively, to specify the reasons for remaining outside the consensus. The findings were shared in a final report and during a concluding conference that was held in Hanoi in November 2012.

\subsection{Defining consensus and importance}

Crucial in a Delphi study is defining when the group has arrived at a consensus. Most studies use quantitative and statistical measures such as mean, median, mode, standard deviation, skewness index, interquartile range, and rank (Espinosa \& Caro,
2011). Depending on the area of research, usually researchers define their own consensus criteria. In this study we use the standard deviation of the total response as a measurement for consensus. Standard deviation (SD) shows how much variation or "dispersion" exists from the average (mean value). A decrease in standard deviation indicates an increase in agreement (Hakim \& Weinblatt, 1993). Related to the targets that were assessed in this study, we used a standard deviation of 2.00 as the cutoff point for a consensus. With a 10-point answering scale with a range from 1 (Unimportant) to 10 (Very important), ICT targets with a standard deviation lower than 2.00 can be considered as targets on which there is a consensus. As the purpose of the study is to identify targets and to measure consensus amongst the group of participants that are selected to represent the broader network of key players in the field, no additional techniques of measuring consensus within subgroups are carried out within the scope of this study.

In this study we use the mean or average of the total response as a measurement for priority or importance. The key players were asked to assess the dimensions as well as the identified targets on a scale from 1 to 10 . To guide their ranking, the following descriptions were provided in Table 2 below:

Targets that have a mean value of 9.00 or higher are considered as crucial or most important. Those with a mean value from 8.00 through 8.99 , are considered as very important. Items with a value from 7.00 through 7.99 are still considered important, but not "most" or "highly" important. Items with a mean value below 7.00 are considered less important.

\section{Findings}

\subsection{Current status of ICT in education in Vietnam}

In 2010, the SEAMEO (2010) identified Vietnam as a "group 2" country: group 2 countries are mainly at the infusing stage for most of the dimensions and most of them already have developed ICT plans and policies in education (SEAMEO, 2010). According to the SEAMEO report, Vietnam has three dimensions of ICT in education in the transforming stage-i.e.: national ICT in education plans and policies; complementary national ICT and education policies; and ICT infrastructure and resources in schools. These may have provided the necessary and sufficient conditions for some schools to transform their ICT-mediated teaching and learning practices. The SEAMEO report was based on case studies on ICT in education submitted in May 2009 by policy makers from 11 SEAMEO member countries. The overall picture that was drawn by the ICT in education key players that participated in the first Delphi round in the beginning of 2012 is somehow less optimistic than the SEAMEO report. Most key players did not think that plans and policies on ICT in education or infrastructure and resources are at the transforming stage. The mean score for "national ICT in education vision" was only 1.75 (on a scale from 1 (emerging) to 4 (transforming)). The key players observed a gap between different education levels: while, as observed by the key players, higher education institutions are mostly at the infusing stage for different dimensions, in secondary and especially primary education some dimensions are still in the applying and even emerging stages.

Table 2

Description ranking scale of identified targets.

$\begin{array}{ll}1 \text { - Unimportant } & \text { No priority; no relevance; no measurable effect; should be dropped as an item to consider } \\ 4 \text { - Slightly important } & \text { Insignificantly relevant; third-order priority; has little importance; not a determining factor for a major issue } \\ 7 \text { - Important } & \begin{array}{l}\text { Is relevant to the issue; second order priority; significant impact but only after other items are considered; } \\ \text { does not have to be fully resolved }\end{array} \\ & \text { A highly relevant item; first order priority; a determining factor for major issues; must be resolved, dealt with, or considered } \\ 10 \text { - Very important } & \end{array}$


After assessment of the current status, key players were requested to list priorities or provide suggestions for realistic targets to achieve by 2020 related to each of the 10 dimensions. These were open questions that led to a large amount of input from the key players. After assessment of overlap, 97 targets were identified and these were categorized in the 10 dimensions and different sub-dimensions which reflect specific aspects of ICT in education. In the second survey round, consensus was achieved on the importance of 62 (63.9\%) of these items (see overview of items per dimension in Appendix A). Of these 62 items, 32 were on average perceived as very important $(9.00>$ Mean $\geq 8.00)$ and 5 had a mean score of 9.00 or higher (crucial or most important). The rest of these items (25) were still considered important $(7.00 \leq$ Mean $<8.00)$ (see Table 3$)$.

\subsection{Achieved consensus on identified targets on ICT in education in Vietnam for 2020}

In what follows we give a description of the targets which the key players agreed are very important (32 targets, $9.00>$ Mean $\geq 8.00)$ or crucial $(5$, Mean $\geq 9.00)$ in the second survey round (see appendix A). Related to "Infrastructure and resources" (Dimension 1), the key players agreed that it is very important to target for a learning management system in all Higher Education (HE) institutions, to have digital resources for teachers and students accessible via an online portal, and to aim for a reduced digital divide of ICT opportunities between poor rural schools and better-off urban schools. On average, they agreed that it is most important to target for Wi-Fi internet access in all HE institutions. A lot of items (15) on which consensus on importance was achieved in this survey round are related to "Teaching and learning pedagogies" (Dimension 2). On average, the key players concurred that it is crucial to promote cooperative learning and teamwork skills, critical thinking, research, problem solving and decision making skills, as well as self-study and self-improvement skills. In addition they agreed that it is very important to promote a learner centered approach with active participation of students, to promote experimental learning and extra-curricular activities for holistic development and to review the curriculum to allow more autonomy for teachers and students. Furthermore they were in agreement that it is very important to promote creativity and initiative, but also language skills and basic ICT skills and knowledge at lower grades. Finally they also concurred that it is very important to target for application of ICT for research and collaborative learning.

Also in the qualitative comments there was a clear consensus on the importance of targets related to the promotion of particular teaching and learning pedagogies and to promote 21 st century knowledge and skills.
"It would be valuable if schools attempt to incorporate studentcentered active learning within the curriculum. However, that cannot be too drastic. An important starting point would be to allow teachers to have more autonomy in teaching" (R3, education specialist, development partner).

"The approach of learner-centered teaching with the active participation of learners is an important factor to educational reform. Currently this does not take place effectively in Vietnamese education. So it is really important and necessary to address and promote it more substantively and more properly" (R15, educational researcher, public sector).

The key players were also in consensus on the importance of ICT knowledge and skills to be addressed in "Professional development for teachers and school leaders" (Dimension 3). They agreed, for example, that basic ICT knowledge and skill training for teachers and managers was very important, as well as subject specific ICT training for teachers, and training on ICT for active teaching and learning. There was agreement on the importance of targeting for the use of ICT to deliver the national curriculum (Dimension 4) by promoting e-learning and blended learning, and by promoting cooperation (local and international) on ICT in education with the participation of the public and private sector and (overseas) development assistance. In addition, it was agreed that the use of ICT to support community participation in education (Dimension 5) should also be targeted. Few items on which little or no consensus was achieved were related to “Assessment" (Dimension 6) and "Evaluation \& research" (Dimension 7), even though most key players agreed that it is very important to promote research as a basis for proper policy formulation on ICT in education.

On average, key players were in consensus that it is very important to target for a national vision (Dimension 8) that focuses on education and learning and a vision that is holistic, taking into consideration different factors of quality of education. There was, moreover, consensus on the importance of the six items related to "National ICT in education policies \& plans" (Dimension 9) as well as on the three items related to “Complementary policies and plans" (Dimension 10), indicating a strong belief in the importance of planning and policy development in general. Most key players agreed that it is most important, for example, that a national policy and plan on ICT in education should be in line with the national visions on ICT in education and that it be accompanied by a specific financial plan. They also agreed that it is important that teacher professional development be included in these plans, that these plans be comprehensive and cohesive, and that all stakeholders assist in their implementation. Finally key players also agreed that policies

Table 3

Distribution of items (second survey round).

\begin{tabular}{|c|c|c|c|c|c|c|}
\hline Dimension & Total & Important & $\begin{array}{l}\text { Very } \\
\text { important }\end{array}$ & $\begin{array}{l}\text { Crucial or most } \\
\text { important }\end{array}$ & $\begin{array}{l}\text { Total } \\
\text { consensus }\end{array}$ & $\begin{array}{l}\text { No } \\
\text { consensus }\end{array}$ \\
\hline (1) ICT infrastructure and resources in schools & 13 & 3 & 3 & 1 & 7 & 6 \\
\hline (2) Teaching and learning pedagogies & 17 & 3 & 8 & 4 & 15 & 2 \\
\hline (3) Professional development for teachers/school leaders & 14 & 3 & 3 & 0 & 6 & 8 \\
\hline (4) ICT in the national curriculum & 8 & 3 & 2 & 0 & 5 & 3 \\
\hline (5) Community/partnerships & 16 & 4 & 3 & 0 & 7 & 9 \\
\hline (6) Assessment & 9 & 5 & 1 & 0 & 6 & 3 \\
\hline (7) Evaluation \& research & 5 & 4 & 1 & 0 & 5 & 0 \\
\hline (8) National ICT in education vision & 6 & 0 & 2 & 0 & 2 & 4 \\
\hline (9) National ICT in education policies \& plans & 6 & 0 & 6 & 0 & 6 & 0 \\
\hline (10) Complementary policies \& plans & 3 & 0 & 3 & 0 & 3 & 0 \\
\hline Total & 97 & 25 & 32 & 5 & 62 & 35 \\
\hline
\end{tabular}


and plans should be developed with involvement of all teachers, students and other stakeholders.

\subsection{Controversial targets}

In the second survey round, no consensus was achieved on 35 items (see Table 3, SD $\geq 2.00$ ). However, in the third and final round of the study, the key players could re-evaluate the importance of these targets. At that point, consensus was achieved on 29 of the 35 items (see overview of items per dimension in Appendix B). Nevertheless it is clear, as also seen in the related qualitative comments, that these items addressed more controversial issues on which the key players had different opinions. On the one hand, some of these targets seemed to be too ambitious for some key players in the current educational context in Vietnam. On the other hand, for some key players some items were no longer important or appropriate when the target is to integrate ICT in education, rather than replace traditional ways of teaching. For example, related to Internet access in all schools, one key player commented as follows:

"It is not really necessary to have Internet in the classroom at this time (depending on schools' conditions), because class size is big in Vietnam so it is difficult to manage the class" (R15, educational researcher, public sector).

The same key player also commented that “... in order to change the quality and learning and teaching activities, it is necessary to have a learning resource center which students can easily access, get information for learning activities."

About "Open resource centers in all schools" and "A computer lab in all schools" another key player made the following remarks:

"In every school, it's very important to have a computer lab. However, at this stage, many schools are equipped with a computer lab already. So I don't think it should be a priority at this moment" (R24, trainer/learning facilitator, development partner).

Another key player commented on this issue as follows:

"School labs are vital to ensure an environment for students to practice using ICT. In addition, in the classrooms, there should be computers connected to projectors for teaching and learning activities" (R21, educational researcher, public sector).

Also the target to have "students in HE institutions bring their own device (laptop, smartphone, tablet, ...)" evoked strong comments. One key player vehemently opposed this target, as it would create a digital divide between haves and have-nots. Again, some key players expressed the belief that the current time is too early for Vietnam to adopt this policy - for example:

"Access to ICT is very crucial to students. However, students do not need to bring their own laptops or mobile phones. Although mobile learning is growing fast now, I don't think Vietnam is ready for this yet" ( $R 24$, trainer/learning facilitator, development partner).

For most of these items related to "Connectivity and access to resources in schools" (Dimension 1), no consensus was achieved in the final survey round either. Key players only agreed on the importance of having internet access in classrooms in all schools and of targeting for more educational applications in Vietnamese. Moreover, in the third survey round, key players came to an agreement that it is less important (Mean $<7.00$ ) to offer all public school books as e-books. However, in both the second and third survey rounds there was no consensus on the target to digitalize all textbooks.
Of particular interest was the target to have "ICT to partly replace teaching staff where there is a shortage" on which there was no consensus (under Dimension 2: "Teaching and learning pedagogies").

One the one hand, one key player argued that:

"Future studies will not require regular school attendance. Pupils, students or teachers will not have to go to school. They will be able to teach and learn through the Internet" (R17, technology developer, private sector).

Another key player added that:

"Priority should be given to developing ICT to partially replace teachers and textbooks" (R13, university professor, public sector).

On the other hand, there were also strong arguments that ICT cannot replace teachers:

“I don't think ICT can ever replace teaching staff. And it doesn't sound like a good reason to use ICT. It can be used to promote distance education, where their might be less teaching staff, or where the teaching profession takes other forms" (R5, educational researcher, development partner).

In the final survey round, most key players agreed that this target is not important (Mean $<7.00$ ).

Even though there was a consensus on the importance of addressing "ICT in professional development of teachers and school leaders" (Dimension 3, see also paragraph 6.3.), there were different opinions on the modalities to provide professional development, especially regarding guidelines and standards for teachers, as illustrated by the following comments:

"The core factor for teachers is their self-awareness to improve their application of ICT through research and teaching. National trainings of the Ministry of Education and Training are not effective. The guidelines and standards on ICT in education for teachers are too simple" (R21, educational researcher, public sector).

"I think it is difficult to create concrete guidelines and standards when ICT in education is very much evolving. It is important though to reserve sometime in the pre-service curriculum. For in-service I believe in the power of communities of practice where teachers can teach and inspire each other" (R5, educational researcher, development partner).

Even though there was no consensus on the target to have learning communities or communities of practice (CoP) for teachers, or to have an online platform to facilitate a national community of teachers (under Dimension 5: Community/partnerships), the qualitative comments in the second survey round explicitly mentioned the idea of a CoP as an important modality for continuing professional development.

"CoP is the best modality for any type of learning but hard to achieve without good facilitation and motivation" (R3, education specialist, development partner).

"When teachers already have the basic skills on ICT, they need to have a CoP (simply an active forum) or a learning environment right in their school so that they could share and exchange their opinions" (R24, trainer/learning facilitator, development partner).

Only after re-evaluation in the final survey round did the key players achieve a strong consensus on the importance and relevance of the concept of $\mathrm{CoP}$ for exchanging experiences and 
learning and agreed to target, for example, learning communities for students and inter-school cooperation. At that point the key players also agreed to target for learning communities for teachers as well as ICT in education guidelines and standards (under Dimension 3: ICT in professional development of teachers and school leaders).

A similar process of consensus building was observed related to ICT in the national curriculum (Dimension 4). In the second survey round some key players saw it as a "necessity" to include basic ICT knowledge and skills in the national curriculum, while others commented that "basic ICT skills should be done as selfstudy, not in the national curriculum." In the final round, however, the key players did come to a consensus that it is important to include basic ICT knowledge and skills in the national curriculum at all levels. No consensus was reached, however, on having standardized testing and certification of basic ICT knowledge and skills.

Related to assessment (Dimension 6) some key players identified a need for a drastic overhaul of the assessment practice in Vietnam:

"Assessment, tests and examinations need an overhaul so that it reflects the way we teach" (R2, service provider, public sector).

"These recommendations related to assessment are in line with each other and very important. Without a change in assessment, all other priorities only target integration in, and not a transformation of, education" (R5, educational researcher, development partner).

Otherwise, consensus on assessment was achieved only in the final survey round in respect of a few specific targets - for example: targeting for competence-based, formative student assessment, and for assessing the holistic development of students.

\section{Conclusions and discussion}

In this Delphi study we have explored how a group of key players, representing the public and private sectors as well as development partners in Vietnam look at the future of ICT in education in the country. The topic is very relevant, as the key players identified 97 different targets to aim for, addressing 10 dimensions of ICT in education. Moreover, there was a high level of consensus on the importance of most of these targets. Many items on which there was a consensus were related to aspects of teaching and learning. As observed elsewhere (e.g. in Liu and Velasquez in Jamieson-Proctor, Watson, Finger, Grimbeek, \& Burnett, 2007) most agree that in education, the purpose of technology integration is to achieve learning goals and enhance learning - not to use fancy technology tools. It is perceived that the innovation lies not per se in the introduction and use of ICT, but in its role as a contributor towards a student-centered form of teaching and learning (Scrimshaw, 2004). In line with those targets related to aspects of teaching and learning, the key players agreed that it is most important to target for improved access to ICT in schools, for teachers and students. The key players agreed on the potential of ICT to deliver the national curriculum by promotion of e-learning and blended learning as well as for support to community participation in education. Apart from improved access, the key players agreed to also target for improved professional development for teachers and school leaders, not only on basic ICT skills, but also on skills to integrate ICT into teaching and learning. This vision on the role of ICT in education as contributing to enhance teaching and learning is a powerful rhetorical device to promote positive change in the present state of education. When it comes to very concrete ideas and targets, especially related to access to ICT in schools, key players, however, seemed still to be in disagreement at the end of the survey. In the last survey round, the key players did come to a consensus that it is not important to target for ICT as a replacement for teachers and that it is important to target for internet access in all schools.

The discussions in the survey rounds were in fact not so much about ICT in education, but more about how the key players perceived education itself. It is understood that ICT-driven developments challenge many assumptions about what students should learn in schools and how education should be delivered (Voogt, 2010). UNESCO (2004) argues, for example, that the potential of ICT may not be optimized if there is no shift in the education paradigm. In a study on ICT in education in Vietnam, Nykvist, Lloyd, and Vui (2003) argue that to achieve the full potential of ICT in education, education in Vietnam would need to undergo major reforms and changes that have more to do with pedagogy and curriculum than the mere acquisition of ICT skills for teachers and providing schools with computer networks. In the second survey round, key players agreed on the potential of ICT applications for teachers for continuing assessment or testing, for self-regulated achievement assessment for students and for student peer assessment. Some key players argued also for a drastic overhaul of the assessment practice in Vietnam. But it was only in the final survey round that all key players came to a consensus on the importance of related targets. Some key players promoted the idea of learning in communities of practice, not only for students, but also for teachers. However, consensus was reached on the importance to target online learning communities for teachers and learners only in the third and final survey round. In general, there is more controversy on more ambitious targets which could potentially transform education in Vietnam. In other contexts, researchers have identified this as an integration mindset which favors existing ways of doing things. They argue that there is a well-established pattern of applying or integrating new technologies into existing practices (Bigum \& Rowan, 2008). Teaching staff tend to learn to use those technologies that can be incorporated into their existing teaching activities most easily, rather than those which could most radically change teaching and learning practices (Kirkup \& Kirkwood, 2005). School systems organized around age-grading, traditional curricular sequencing and accepted professional accreditation have struggled in adapting to new, learner-directed technologies (Collins \& Halverson, 2009).

According to Collins and Halverson (2009) we already have a vibrant, highly charged discussion about the goals of education. They argue that parents, citizens and policymakers need to continue to push for a more expansive view of education reform, and to address how new technologies can help us reshape the institutions that we have come to rely upon. The application of the Delphi technique in this study has contributed to consensus making on more controversial targets and focused the debate on education reform. The policy Delphi method's unique strength is that it incorporates education and consensus-building into the multistage process of data collection, thus enabling depiction of agreement about specific policy options among key players (Rayens \& Hahn, 2000). Based on the strong qualitative arguments of some panel members in the second survey round, consensus was achieved on most targets ( 29 out of 35 ) in the final round. However, researching the future is not a one-off exercise in forecasting. Facer and Sandford (2009) describe the exploration and creation of future possibilities as an ongoing activity. The Delphi exercise reported on in this paper can be considered as kicking off continuing debate on education reform and the role of ICT therein. To keep the momentum going, it is important that findings lead to policy development. Also participants in this study agreed that it is important that policies and plans should be developed with involvement of all stakeholders, and that research should be 
promoted as the basis for proper policy formulation on ICT in education.

\section{Reflection on lessons learned}

Rayens and Hahn (2000) believe that taking part in the Delphi process can be a highly motivating experience for participants. However, time frames for conducting and completing a study, the possibility of low response rates, and unintentionally guiding feedback from the respondent group are areas which must be considered when designing and implementing a Delphi study (Hsu \& Sandford, 2007).

An important issue of this study was the engagement of the panelists. Due to the multiple feedback processes integral to the concept and use of the Delphi process, the potential existed for low response rates. Motivation of the panelists is one way to lessen the problem of drop-out. In this study, we had to stay in contact with panelists during data collection and analysis phases. We opted for an online administration of the survey rounds, published and shared reports on the findings of each survey round and organized face to face key players meetings to consolidate important steps in the process. Several reminders had to be send to the panelists in order to avoid drop-out for the online survey rounds. This made the administration of the study very time consuming, as also warned for by Hsu and Sandford (2007). A comparative study of Geist (2010) shows that participation rates can be better with paper-pencil versions in comparison with a computer version. We could have opted for face-to-face interviews with paper-pencil version, as most key players resided in Vietnam and/or could be met by the researchers; or for sending the questionnaire by postal mail. We believe however that online data collection increased the sense of anonymity of the key players involved in the study.

Another important issue in this study was the role of the investigator in the process of consensus building. Altschuld (in Hsu \& Sandford, 2007) warns that the iteration characteristics of the Delphi method can potentially enable investigators to mold opinions. In this study, we had a significant role in the categorization of the targets that were developed by the key players in the initial Delphi round. We categorized these targets according to the dimension and sub-dimension of ICT in education that were introduced in the first key players meeting. Afterwards, in the two following survey rounds, we reported on how the group responded as a whole, and provided the qualitative comments that the key players shared on specific targets. This descriptive quantitative and qualitative data were used to facilitate the consensus building process, which is one of the particular strengths of the policy Delphi we wanted to apply in this study. We argued that strong qualitative comments of particular key players played an important role in the consensus-building process. It would be interesting for future research to study in depth how exactly this consensus was achieved and the importance of the administration of the study and the role of the involved participants herein.

\section{Acknowledgments}

This study took place in the framework of a development cooperation program of the Flemish Association for Development Cooperation and Technical Assistance. The first author would like to thank his colleague, Mrs. Tran Nu Mai Thy who assisted in the data collection process and Mr. John Bently for proof reading of the paper. The authors highly appreciate the key players for their contribution to the study.

\section{Appendix A}

Sixty-two items on which consensus on the importance has been achieved and ranked from highest to lowest level of perceived importance (mean values). ${ }^{3}$

\begin{tabular}{|c|c|c|c|}
\hline \multicolumn{4}{|c|}{ Crucial-most important targets } \\
\hline Item & Description & Mean & SD \\
\hline 2.12 . & Promotion of self-study and self-improvement skills & 9.23 & 1.07 \\
\hline 2.8 & $\begin{array}{l}\text { Promotion of critical thinking, research, } \\
\text { problem solving and decision making skills }\end{array}$ & 9.19 & 0.98 \\
\hline 2.11 . & $\begin{array}{l}\text { Promotion of collaborative learning and } \\
\text { teamwork skills }\end{array}$ & 9.12 & 0.95 \\
\hline 2.5 . & Promotion of cooperative learning & 9.04 & 1.15 \\
\hline 1.6. & Wi-Fi internet access in all HE institutions & 9.00 & 1.17 \\
\hline \multicolumn{4}{|c|}{ Very important targets } \\
\hline Item & Description & Mean & SD \\
\hline 1.7. & $\begin{array}{l}\text { Learning management system in all HE } \\
\text { institutions }\end{array}$ & 8.96 & 1.46 \\
\hline 2.9 . & Promotion of creativity and initiative & 8.96 & 1.15 \\
\hline 9.5 . & ICT is integral to overall school development plan & 8.92 & 1.23 \\
\hline 2.1. & $\begin{array}{l}\text { Promotion of a learner centered approach with } \\
\text { active participation of students }\end{array}$ & 8.73 & 1.49 \\
\hline 2.10 . & Promotion of language skills & 8.62 & 1.24 \\
\hline 5.15 & $\begin{array}{l}\text { ICT to monitor educational quality and change } \\
\text { in schools }\end{array}$ & 8.62 & 1.44 \\
\hline 9.6. & $\begin{array}{l}\text { Policies and plans developed with involvement } \\
\text { of teachers and students }\end{array}$ & 8.62 & 1.23 \\
\hline 2.7. & $\begin{array}{l}\text { Review curriculum to allow more autonomy for } \\
\text { teachers and students }\end{array}$ & 8.58 & 1.30 \\
\hline 3.4. & $\begin{array}{l}\text { Training on ICT for active teaching and learning } \\
\text { for teachers }\end{array}$ & 8.58 & 1.45 \\
\hline 9.4 . & $\begin{array}{l}\text { Comprehensive and cohesive policies and plans } \\
\text { that assist all stakeholders in implementation }\end{array}$ & 8.58 & 1.33 \\
\hline 1.13. & $\begin{array}{l}\text { Reduced digital divide of ICT opportunities } \\
\text { between poor rural schools and better-off } \\
\text { urban schools }\end{array}$ & 8.54 & 1.99 \\
\hline 9.3 . & $\begin{array}{l}\text { Inclusion of teacher professional development } \\
\text { in national ICT in education policies and plans }\end{array}$ & 8.54 & 1.45 \\
\hline 8.1. & Vision focuses on education and learning & 8.46 & 1.45 \\
\hline 10.1 . & $\begin{array}{l}\text { National ICT in education policies start from a } \\
\text { clear national vision on ICT in education }\end{array}$ & 8.46 & 1.21 \\
\hline 1.9. & $\begin{array}{l}\text { Digital resources for teachers and students } \\
\text { accessible via an online portal (Open } \\
\text { Educational Resources-OER) }\end{array}$ & 8.42 & 1.70 \\
\hline 5.16 . & $\begin{array}{l}\text { Wide application of ICT in the community to } \\
\text { bring communities together }\end{array}$ & 8.42 & 1.33 \\
\hline 3.1. & $\begin{array}{l}\text { Basic ICT knowledge and skills training for } \\
\text { teachers and managers }\end{array}$ & 8.38 & 1.79 \\
\hline 3.10 . & $\begin{array}{l}\text { Hands-on practice as part of professional } \\
\text { development programs }\end{array}$ & 8.38 & 1.55 \\
\hline 4.6. & $\begin{array}{l}\text { Promotion of blended learning (online and face } \\
\text { to face) }\end{array}$ & 8.38 & 1.88 \\
\hline 5.1. & $\begin{array}{l}\text { Promotion of cooperation (local and } \\
\text { international) on ICT in education with the } \\
\text { participation of the public and private sector } \\
\text { and (overseas) development assistance }\end{array}$ & 8.31 & 1.44 \\
\hline 10.2 & $\begin{array}{l}\text { The ICT in education policies complement the } \\
\text { national ICT and education policies }\end{array}$ & 8.31 & 1.16 \\
\hline 6.6. & $\begin{array}{l}\text { Students use multiple media to demonstrate } \\
\text { attainment }\end{array}$ & 8.27 & 1.19 \\
\hline 2.15 . & $\begin{array}{l}\text { Application of ICT for research and } \\
\text { collaborative learning (innovation in } \\
\text { developing social networks, school wikis, and } \\
\text { other platforms) }\end{array}$ & 8.23 & 1.18 \\
\hline 2.13 . & $\begin{array}{l}\text { Promotion of basic ICT skills and knowledge at } \\
\text { lower grades }\end{array}$ & 8.19 & 1.44 \\
\hline 9.2 . & $\begin{array}{l}\text { National policy and plan on ICT in education } \\
\text { accompanied by a specific financial plan }\end{array}$ & 8.19 & 1.42 \\
\hline 8.5 . & $\begin{array}{l}\text { Vision is holistic, taking in consideration } \\
\text { different factors of quality of education }\end{array}$ & 8.15 & 1.95 \\
\hline 9.1. & $\begin{array}{l}\text { Increased participation of all stakeholders in } \\
\text { the development of policies and plans }\end{array}$ & 8.12 & 1.58 \\
\hline
\end{tabular}

\footnotetext{
${ }^{3}$ All items are numbered per dimension (first digits, from dimension 1 to
} dimension 10), as specified in Table 3. 
Appendix A (Continued)

\begin{tabular}{llcc}
\multicolumn{2}{c}{ Very important targets } & & \\
Item & Description & Mean & SD \\
\hline 2.3. & Promotion of experimental learning & 8.08 & 1.98 \\
$7.1 . \quad \begin{array}{l}\text { Promotion of research as a basis for proper } \\
\text { policy formulation on ICT in education }\end{array}$ & 8.08 & 1.60 \\
2.6. & $\begin{array}{l}\text { Promotion of extra-curricular activities for } \\
\text { holistic development }\end{array}$ & 8.04 & 1.43 \\
4.5. & Promotion of e-learning & 8.04 & 1.93 \\
10.3 & Building IT skills integrated in national & 8.04 & 1.76
\end{tabular}

development strategies (e-government

program, e-citizens, etc)

\section{Important targets}

\begin{tabular}{|c|c|c|c|}
\hline Item & Description & Mean & SD \\
\hline 3.3. & ICT training for material developers (digital content) & 7.96 & 1.71 \\
\hline 6.8. & $\begin{array}{l}\text { ICT applications for teachers for continuous } \\
\text { assessment or final testing }\end{array}$ & 7.96 & 1.43 \\
\hline 2.4 & Promotion of holistic student development & 7.92 & 1.96 \\
\hline 2.14 & $\begin{array}{l}\text { Application of ICT in teaching for holistic } \\
\text { development of students }\end{array}$ & 7.92 & 1.62 \\
\hline 4.8. & $\begin{array}{l}\text { Development of Open Educational Resources } \\
\text { (OER) linked to the curriculum in all subjects }\end{array}$ & 7.92 & 1.65 \\
\hline 6.5 . & $\begin{array}{l}\text { Different types of assessment (formative and } \\
\text { summative assessment) for different levels of } \\
\text { competence }\end{array}$ & 7.92 & 1.99 \\
\hline 6.7. & $\begin{array}{l}\text { ICT applications for students for self regulated } \\
\text { achievement assessment }\end{array}$ & 7.92 & 1.47 \\
\hline 3.2. & Subject-specific ICT training for teachers & 7.88 & 1.24 \\
\hline 4.2 . & Application of ICT integrated in other subjects & 7.81 & 1.72 \\
\hline 5.4 . & $\begin{array}{l}\text { More focus on expanding international } \\
\text { markets, diversification of services in ICT to } \\
\text { enhance the competitiveness of Vietnamese } \\
\text { enterprises }\end{array}$ & 7.81 & 1.79 \\
\hline 7.4. & $\begin{array}{l}\text { Enhanced research and development capacity } \\
\text { of ICT in education research institutions }\end{array}$ & 7.81 & 1.63 \\
\hline 1.3. & $\begin{array}{l}\text { Access to a computer/laptop and projector for } \\
\text { classroom teaching in all schools }\end{array}$ & 7.77 & 1.66 \\
\hline 5.13. & $\begin{array}{l}\text { Increased accountability of schools towards } \\
\text { parents and the community }\end{array}$ & 7.73 & 1.95 \\
\hline 2.16. & $\begin{array}{l}\text { Application of ICT within and outside the school } \\
\text { environment }\end{array}$ & 7.69 & 1.52 \\
\hline 5.12. & $\begin{array}{l}\text { Promotion of participation of parents and } \\
\text { communities in education (in secondary and } \\
\text { primary education) }\end{array}$ & 7.69 & 1.96 \\
\hline 6.9 . & Student peer assessment (facilitated by ICT) & 7.69 & 1.78 \\
\hline 4.4 . & Classes for talented ICT students & 7.62 & 1.88 \\
\hline 7.3. & $\begin{array}{l}\text { Formative and summative evaluation of ICT in } \\
\text { education }\end{array}$ & 7.58 & 1.86 \\
\hline 7.5. & $\begin{array}{l}\text { Involvement of educators in action research, } \\
\text { lesson study and/or design based research on } \\
\text { ICT in education }\end{array}$ & 7.58 & 1.84 \\
\hline 7.2 . & $\begin{array}{l}\text { Monitoring and evaluation of system } \\
\text { performance parallel with an ICT in education } \\
\text { plan (Planning, Monitoring \& Evaluation) }\end{array}$ & 7.46 & 1.73 \\
\hline 5.2. & $\begin{array}{l}\text { Targets for annual private investment for ICT } \\
\text { equipment in schools }\end{array}$ & 7.42 & 1.47 \\
\hline 3.9. & $\begin{array}{l}\text { Thematic training package for self-study for } \\
\text { teachers defined by MOET (in-service) }\end{array}$ & 7.35 & 1.90 \\
\hline 1.10. & $\begin{array}{l}\text { Availability of a wide range of specific software } \\
\text { for specific subjects }\end{array}$ & 7.27 & 1.97 \\
\hline 6.1. & Integrated portfolio assessment across subject areas & 7.12 & 1.99 \\
\hline 1.2. & Classroom computers in all schools & 7.04 & 1.51 \\
\hline
\end{tabular}

\section{Appendix B}

Thirty-five items on which no consensus on the importance has been achieved in the second survey round. ${ }^{4}$

\footnotetext{
${ }^{4}$ All items are numbered per dimension (first digits, from dimension 1 to dimension 10), as specified in Table 3.
}

Item

\section{Survey round}

Item Description

1.1. A computer lab in all schools

1.4. Internet access in classrooms in all schools

1.5. Open resource centers in all schools with access to i.e. digital camera, scanner, printer, video camera, recorder, video conference system, subject specific software, etc.

1.8. In HE institutions students bring their $\quad \begin{array}{lllll}6.92 & 2.43 & 6.59 & 2.15\end{array}$ own device (laptop, smartphone, tablet, etc.)

1.11. All public school books (the curriculum) are offered as e-books

1.12. More educational applications in Vietnamese (created by Vietnamese)

2.2. Promotion of multi-sense learning styles

2.17. ICT to partly replace teaching staff where there is a shortage

3.5. English language training on ICT in education

3.6. Management skills training on promotion of active teaching and learning methodologies

3.7. Management skills training on promotion of 21st century skills

3.8. Self-managed and needs-based study for teachers with support of the school

3.11. ICT in education guidelines and standards for teachers

3.12. ICT in education in the curriculum for pre-service

3.13. National ICT in education teacher exam with certification

3.14. Learning communities (or communities of practice) for teachers (for example on EDUnet)

4.1. Basic ICT knowledge and skills in national curriculum at all levels

4.3. Standardized testing and certification of basic ICT knowledge and skills (for example the International Computer Driving License - ICDL)

4.7. Digitalization of all textbooks

5.3. Departments in educational institutions in charge of cooperation and funding

5.5. Schools have learning communities fo students to exchange on learning and related issues

5.6. Schools have learning communities for teachers per subjects for peer coaching and support

5.7. Inter-school cooperation communities

5.8. Online platforms (for example EDUnet) to facilitate a national community of educators

5.9. Regional and international online learning communities for teachers and students

5.10. Local to global learning communities on environment and sustainable development issues

5.11. School as an academic resource for the community - either directly or online

5.14. Involvement of the community in evaluation of educational quality and change students

6.3. Competence based, formative student assessment

6.4. Assessment in line with a competence based curriculum and activating teaching and learning pedagogies

\begin{tabular}{lllll}
\multicolumn{2}{c}{ 2nd round } & & \multicolumn{2}{c}{ 3rd round } \\
\cline { 1 - 2 } \cline { 5 - 5 } Mean & SD & & Mean & SD \\
\hline 7.62 & 2.42 & & 7.86 & 2.30 \\
7.46 & 2.04 & & 7.68 & 1.73 \\
7.73 & 2.07 & & 6.91 & 2.45
\end{tabular}


Appendix B (Continued)

\begin{tabular}{|c|c|c|c|c|c|}
\hline \multicolumn{2}{|c|}{ Survey round } & \multicolumn{2}{|c|}{ 2nd round } & \multicolumn{2}{|c|}{$\underline{3 r d}$ round } \\
\hline Item & Description & Mean & SD & Mean & SD \\
\hline 8.2 . & $\begin{array}{l}\text { Vision focuses on driving changes in } \\
\text { culture, policies and practices mediated } \\
\text { by ICT }\end{array}$ & 7.46 & 2.23 & 8.14 & 1.24 \\
\hline 8.3. & $\begin{array}{l}\text { Vision is in line with the current status } \\
\text { of the economy, culture and practices }\end{array}$ & 7.31 & 2.24 & 7.76 & 1.45 \\
\hline 8.4 & $\begin{array}{l}\text { Vision is result and output oriented } \\
\text { rather than input oriented }\end{array}$ & 7.38 & 2.39 & 7.86 & 1.28 \\
\hline 8.6. & $\begin{array}{l}\text { Vision on infrastructure and resources } \\
\text { focuses on the most needy schools }\end{array}$ & 7.42 & 2.28 & 7.76 & 1.26 \\
\hline
\end{tabular}

\section{References}

Balasubramanian, K., Clark-Okah, W., Daniel, J., Fererira, F., Kanwar, A., Kwan, A., et al. (2009). ICTs for higher education: Background paper from the Commonwealth of Learning. Paper presented at the UNESCO world conference on higher education.

Bigum, C., \& Rowan, L. (2008). Landscaping on shifting ground: Teacher education in a digitally transforming world. Asia-Pacific Journal of Teacher Education, 36(3), 245-255.

Clegg, S., Hudson, A., \& Steel, J. (2003). The Emperor's New Clothes: Globalisation and elearning in higher education. British Journal of Sociology of Education, 24(1), 39-53.

Collins, A., \& Halverson, R. (2009). The second educational revolution: Rethinking education in the age of technology. Journal of Computer Assisted Learning, 26(1), $18-27$.

Drent, M., \& Meelissen, M. (2008). Which factors obstruct or stimulate teacher educators to use ICT innovatively? Computers E' Education, 51(1), 187-199.

Espinosa, K. J. P., \& Caro, J. D. L. (2011). A real-time web-based Delphi study on ICT integration framework in Basic Education. Paper presented at the international conference on telecommunication technology and applications.

Facer, K., \& Sandford, R. (2009). The next 25 years? Future scenarios and future directions for education and technology. Journal of Computer Assisted Learning, 26(1), 74-93.

Farrell, G., \& Wacholz, C. (Eds.). (2003). UNESCO meta-survey on the use of technologies in education in Asia and the Pacific. Bangkok: UNESCO Asia and Pacific Regional Bureau for Education.

Geist, M. R. (2010). Using the Delphi method to engage stakeholders: A comparison of two studies. Evaluation and Program Planning, 33(2), 147-154.

Groff, J., \& Mouza, C. (2008). A framework for addressing challenges to classroom technology use. AACE Journal, 16(1), 21-46.

Hakim, S., \& Weinblatt, J. (1993). The Delphi process as a tool for decision making: The case of vocational training of people with handicaps. Evaluation and Program Planning, 16(1), 25-38.

Hawkridge, D. (1990). Who needs computers in schools, and why? Computers E Education, 15(1-3), 1-6.

Hong, K., \& Songan, P. (2011). ICT in the changing landscape of higher education in Southeast Asia. Australasian Journal of Educational Technology, 27(8), 1276-1290.

Hsu, C., \& Sandford, A. S. (2007). The Delphi technique: Making sense of consensus. Practical Assessment, Research E Evaluation., 12(10), 1-8.

Hsu, C., \& Sandford, A. S. (2012). The Delphi technique: Use, considerations, and applications in the conventional, policy, and on-line environment. In C. N. Silva (Ed.), Online research methods in urban and planning studies: Design and outcomes (pp. 173-192). Hershey, PA: IGI Global.

Hung, H.-L., Altschuld, J. W., \& Lee, Y.-F. (2008). Methodological and conceptual issues confronting a cross-country Delphi study of educational program evaluation. Evaluation and Program Planning, 31(2), 191-198.

International Telecommunication Union. (2009). Measuring the information societyThe ICT Development Index. Geneva, Switzerland: International Telecommunication Uniono (Document number).

International Telecommunication Union. (2011). Measuring the information societyThe ICT Development Index. Geneva, Switzerland: International Telecommunication Uniono (Document number).

James, P., \& Hopkinson, L. (2009). Sustainable ICT in further and higher education. Bradford (UK): JISCo Document number.

Jamieson-Proctor, R., Watson, G., Finger, G., Grimbeek, P., \& Burnett, P. C. (2007). Measuring the use of information and communication technologies (ICTs) in the classroom. Computers in the Schools, 24(1), 167-184.

John, P., \& Sutherland, R. (2005). Affordance, opportunity and the pedagogical implications of ICT. Educational Review, 57(4), 405-413.

Kirkup, G., \& Kirkwood, A. (2005). Information and communications technologies (ICT) in higher education teaching: A tale of gradualism rather than revolution. Learning, Media, E' Technology, 30(2), 185-199.

Kozma, R. B. (2008). Comparative analysis of policies for ICT in education. In J. Voogt, \& G. Knezek (Eds.), International handbook of information technology in primary and secondary education (20, pp. 1083-1096). New York: Springer.

Linstone, H. A., \& Turoff, M. (2002). The Delphi method: Techniques and applications..

Mills, S. C., \& Tincher, R. C. (2003). Be the technology: A developmental model for evaluating technology integration. Journal of Research on Technology in Education, 35(3), 382.
Mioduser, D., Nachmias, R., Tubin, D., \& Forkosh-Baruch, A. (2003). Analysis schema for the study of domains and levels of pedagogical innovation in schools using ICT. Education and Information Technologies, 8(1), 23-36.

Mumtaz, S. (2000). Factors affecting teachers' use of information and communications technology: A review of the literature. Journal of Information Technology for Teacher Education, 9(3), 319-342.

Novakowski, N., \& Wellar, B. (2008). Using the Delphi technique in normative planning research: Methodological design considerations. Environment and Planning A, 40(6), 1485-1500.

Nykvist, S., Lloyd, M., \& Vui, T. (2003). ICT education in Vietnam: Diving into the second wave. Paper presented at the international conference on computers in education.

Peeraer, J., \& Van Petegem, P. (2011a). Information and Communication Technology in teacher education in an emerging developing country: Vietnam's baseline situation at the start of 'The Year of ICT'. Computers E' Education, 56(4), 974-982.

Peeraer, J., \& Van Petegem, P. (2011b). Information and communication technology in teacher education in Vietnam: from policy to practice. Educational Research for Policy and Practice, 1-15. http://dx.doi.org/10.1007/s10671-011-9106-9

Peeraer, J., \& Van Petegem, P. (2012). Measuring integration of information and communication technology in education: An item response modeling approach. Computers E' Education, 58(4), 1247-1259.

Pollard, C., \& Pollard, R. (2004). Research priorities in educational technology: A Delphi study. Journal of Research on Technology in Education, 37(2), 145-160.

Powell, C. (2003). The Delphi technique: Myths and realities. Journal of Advanced Nursing, 41(4), 376-382.

Power, C. (2007). Educational research, policy and practice in an era of globalisation. Educational Research for Policy and Practice, 6(2), 87-100.

Rayens, M., \& Hahn, E. (2000). Building consensus using the policy Delphi method. Policy, Politics, \& Nursing Practice, 1(4), 308-315.

Robertson, H.-J. (2003). Toward a theory of negativity: Teacher education and information and communications technology. Journal of Teacher Education, 54(4), 280-296.

Scrimshaw, P. (Ed.). (2004). Enabling teachers to make successful use of ICT. Coventry: British Educational Communications and Technology Agency.

SEAMEO (2010). Status of ICT integration in education in Southeast Asian countries. Bangkok: The Southeast Asian Ministers of Education Organization (SEAMEO) (SEAMO o. Document Number).

Selwyn, N. (1999). Why the computer is not dominating schools: A failure of policy or a failure of practice? Cambridge Journal of Education, 29(1), 77-91.

Selwyn, N. (2007). The use of computer technology in university teaching and learning A critical perspective. Journal of Computer Assisted Learning, 23(2), 83-94.

Selwyn, N. (2012). Ten suggestions for improving academic research in education and technology. Learning, Media and Technology, 37(3), 213-219.

Tearle, P. (2003). ICT implementation: What makes the difference? British Journal of Educational Technology, 34(5), 567-583.

Tondeur, J., van Braak, J., \& Valcke, M. (2007). Curricula and the use of ICT in education: Two worlds apart? British Journal of Educational Technology, 38(6), 962-976.

UNESCO (2004). Integrating ICTs into education: Lessons learned. Bangkok: UNESCO Asia and Pacific Regional Bureau for Educationo (Document number).

UNESCO (2005). Regional guidelines on teacher development for pedagogy-technology integration. Bangkok: UNESCO Asia and Pacific Regional Bureau for Educationo (Document number).

UNESCO (2010). ICT transforming education: A regional guide. Bangkok: UNESCO Asia and Pacific Regional Bureau for Education.

Voogt, J. (2010). Teacher factors associated with innovative curriculum goals and pedagogical practices: Differences between extensive and non-extensive ICT-using science teachers. Journal of Computer Assisted Learning, 26(6), 453-464.

Williams, P. (2005). Lessons from the future: ICT scenarios and the education of teachers. Journal of Education for Teaching, 31(4), 319-339.

World Links. (2007). Final report on the Asian Policy Forum on ICT integration into education. Quezon City, Philippines (W. Links o. Document Number)..

Jef Peeraer Thao Vien Guesthouse A3 rm 307, 1B Bac Son-Ngoc Ha, Hanoi, Vietnam jef.peeraer@gmail.com Web: http://www.vvob.be/vietnam/Jef Peeraer works for the Flemish Association for Development Cooperation and Technical Assistance (VVOB) as adviser on M\&E and integration of Information and Communication Technology (ICT). The focus of his research is on education change processes in general and on integration of ICT in education in particular. He is supporting teacher education institutions in Vietnam in operationalizing their vision on education innovation, and developed and implemented capacity building programs for educators in a variety of learning environments.

Peter Van Petegem Venusstraat 35, 2000 Antwerp, Belgium peter.vanpetegem@ua.ac.be Web: http://www.ua.ac.be/main.aspx?c=peter.vanpetegem Peter Van Petegem is full professor of education at the Institute for Education and Information Sciences of the University of Antwerp, Belgium. He is head of the research group Edubron (http://www.edubron.be/) that is focusing on diverse aspects of education including performance indicators as a tool for school improvement, evaluation of educational innovations, policy making capacities of schools, school effectiveness, and environmental education. 